\title{
The Molecular Genetic Background of Familial Hypercholesterolemia: Data From the Slovak Nation-Wide Survey
}

\author{
D. GABČOVÁ ${ }^{1}$, B. VOHNOUT ${ }^{2,3}$, D. STANÍKOVÁ ${ }^{1,4}$, M. HUČKOVÁ ${ }^{1}$, M. KADUROVÁ ${ }^{5}$, \\ M. DEBREOVÁ ${ }^{6}$, M. KOZÁROVÁ ${ }^{6}$, L. FÁBRYOVÁ ${ }^{8}$, SLOVAK FH STUDY GROUP, \\ J. STANÍK ${ }^{1,3,9}$, I. KLIMEŠ ${ }^{1}$, K. RAŠLOVÁ ${ }^{2,3}$, D. GAŠPERIKOVÁ ${ }^{1}$
}

${ }^{1}$ DIABGENE Laboratory, Institute of Experimental Endocrinology, Biomedical Research Center, Slovak Academy of Sciences, Bratislava, Slovakia, ${ }^{2}$ Institute of Nutrition, FOZOS, Slovak Medical University, Bratislava, Slovakia, ${ }^{3} \mathrm{Co}$-ordionation Center for Familial Hyperlipoproteinemias, Slovak Medical University, Bratislava, Slovakia, ${ }^{4}$ First Department of Pediatrics, Medical Faculty of Comenius University, Bratislava, Slovakia, ${ }^{5}$ Specialized Outpatient Clinic for FHLP, Poprad, Slovakia, ${ }^{6}$ Pediatric Endocrinology Outpatient Clinic, Poprad, Slovakia, ${ }^{7}$ Fourth Department of Internal Medicine, Faculty of Medicine, Pavol Jozef Safarik University, Kosice, Slovakia, ${ }^{8}$ Metabol Klinik, Bratislava, Slovakia, ${ }^{9}$ Center for Pediatric Research Leipzig, Hospital for Children \& Adolescents, University of Leipzig, Germany

Received March 14, 2016

Accepted May 20, 2016

On-line November 8, 2016

\section{Summary}

Familial hypercholesterolemia (FH) is most frequently caused by $\angle D L R$ or $A P O B$ mutations. Therefore, the aim of our study was to examine the genetic background of Slovak patients suspected of FH. Patients with clinical suspicion of FH (235 unrelated probands and 124 family relatives) were recruited throughout Slovakia during the years 2011-2015. The order of DNA analyses in probands was as follows: 1. APOB mutation p.Arg3527Gln by real-time PCR method, 2 . direct sequencing of the $L D L R$ gene 3. MLPA analysis of the $L D L R$ gene. We have identified 14 probands and 2 relatives with an $A P O B$ mutation p.Arg3527Gln, and 89 probands and 75 relatives with 54 different $L D L R$ mutations. Nine of $L D L R$ mutations were novel (i.e. p.Asp90Glu, c.314-2A>G, p.Asp136Tyr, p.Ser177Pro, p.Lys225_Glu228delinsCysLys, p.Gly478Glu, p.Gly675Trpfs*42, p.Leu680Pro, p.Thr832Argfs*3). This is the first study on molecular genetics of $\mathrm{FH}$ in Slovakia encompassing the analysis of whole $L D L R$ gene. Genetic etiology of $\mathrm{FH}$ was confirmed in 103 probands (43.8\%). Out of them, $86.4 \%$ of probands carried the $L D L R$ gene mutation and remaining $13.6 \%$ probands carried the p.Arg3527Gln $A P O B$ mutation.

\section{Key words}

Familial hypercholesterolemia $\bullet \mathrm{FH} \bullet L D L R \bullet A P O B \bullet$ Slovakia

\section{Corresponding author}

D. Gašperiková, DIABGENE Laboratory, Institute of Experimental Endocrinology, Biomedical Research Center, Slovak Academy of Sciences, Dúbravská cesta 9, 84505 Bratislava, Slovakia. E-mail: daniela.gasperikova@savba.sk

\section{Introduction}

Familial hypercholesterolemia (FH) is the world's most common heritable disorder of lipid metabolism with the estimated prevalence in general population of 1:200-1:500 (Goldstein et al. 2001, Nordestgaard et al. 2013). The phenotype of FH is characterized by cholesterol depositions in tissues and blood vessels of mutation carriers creating tendon xanthoma, xanthelasma and arcus lipoides corneae (Goldstein et al. 2001). Due to the increased deposition of cholesterol in blood vessels, the atherosclerosis process is accelerated, what leads to a significantly higher risk of premature cardiovascular diseases (CVD) (Goldstein et 
al. 2001, Khachadurian 1988). Therefore, early clinical diagnosis confirmed by the DNA analysis and effective treatment is crucial to reduce the mortality and high risk of premature atherosclerosis complications (Vogt 2015).

From the genetic point of view, the disease is caused by mutations in genes affecting the processing of LDL particles from circulation, resulting in an increase in both LDL cholesterol and total cholesterol, respectively. The most common cause of FH are mutations in the gene encoding LDL receptor $(L D L R)$, followed by mutations in the gene for apolipoprotein $\mathrm{B}(A P O B)$, and rarely mutations in the proprotein convertase subtilisin/kexin 9 gene (PCSK9) (Austin et al. 2004). Currently, 1701 unique variants in the $L D L R$ gene are reported (http://databases.lovd.nl/shared/genes/LDLR). Therefore, each country has its specific spectrum of $L D L R$ mutations. In contrast to this, there are two very prevalent mutations, i.e. p.Arg3527Gln (in Europeans) and p.Arg3527Trp (in Asians) in $A P O B$ gene covering vast majority of the $A P O B$ mutation carriers (Tai et al. 1998).

In this study we aimed to examine the genetic background of patients suspected on FH from Slovak nation-wide survey.

\section{Patients and Methods}

\section{Study design and participants}

Four hundred and thirty two individuals (from 292 families) with a clinical suspicion of $\mathrm{FH}$ were recruited throughout Slovakia over March 2011 - October 2015 following the MED PED Familial Hypercholesterolemia approach. From these, 235 probands fulfilled the inclusion criteria for DNA analysis (modified from (van Aalst-Cohen et al. 2006), which were as follows: LDL cholesterol and/or total cholesterol above $95^{\text {th }}$ percentile for age and gender (Freiberger and Ceska 2007) together with at least one of the following: a) evidence of hyperlipidemia in a first degree relative, b) evidence of CVD (myocardial infarction, stroke) before age of 65 years in the patient or first degree relative, and c. presence of xanthoma or arcus lipoides corneae in the patient/family relative. Patients with secondary cause of hypercholesterolemia (based on the information from the questionnaire) were excluded from the study. Samples of venous blood were collected for DNA analysis, and together with the Informed Consent form and the Questionnaire were transported to the DIABGENE laboratory.

\section{Molecular genetic analyses}

Genomic DNA was extracted from peripheral blood leukocytes using Whole Blood DNA Maxi Preparation Kit (BioTeke Corporation, China). DNA analysis was divided into three consecutive steps (finding a genetic cause of FH in one of them excluded patients from the oncoming DNA analyses).

1) $A P O B$ analysis. Real-time PCR (allelic discrimination) of the most common mutation p.Arg3527Gln in $A P O B$ gene was performed using TaqMan SNP Genotyping Assay ID: c_1026605_10, rs5742904 (Applied Biosystems, Germany) and analyzed using the fast Real-time PCR system 7900HT (ABI, Germany). Data were evaluated using the SDS v2.4 software.

2) Bidirectional sequencing of $L D L R$ gene. Promoter region and all 18 coding exons and exon/intron boundaries of the LDLR gene were amplified by polymerase chain reaction (PCR) using previously described primers (Taylor et al. 2010, Chater et al. 2006, Tichy et al. 2012). PCR products were sequenced using standard protocol on an ABI 3500 (Applied Biosystems, Warrington, UK) and were compared with the reference sequence NM_000527.4 using SeqScape software (version 2.1.1; Applied Biosystems, Warrington, UK). Novelty of the identified missense mutations was verified in the mutation database (http://databases.lovd.nl/ shared/genes/LDLR) and published resources. Consequently, the pathogenicity was tested by in silico analyses (SIFT, PolyPhen-2, Mutation Taster and HSF).

3) MLPA (Multiplex ligation probe amplification) of all exons of $L D L R$ was performed using SALSA MLPA KIT P062-C2 (MRC-Holland) and analyzed on ABI-3500 genetic analyzer. MLPA data were evaluated using GeneMarker v1.95 (SoftGenetics, USA).

\section{Biochemical analyses}

Lipid analyses were performed in local certified laboratories in Slovakia with appropriate quality controls. Serum total cholesterol (TC), HDL-cholesterol (HDL-C), and triglyceride (TG) levels were measured using fully automated enzymatic methods. LDL-cholesterol levels were calculated using the Friedewald formula (in case TG levels were $<4.5 \mathrm{mmol} / \mathrm{l}$; when TG levels exceeded $4.5 \mathrm{mmol} / \mathrm{l}$, LDL cholesterol values were considered missing and/or measured by direct method). 


\section{Statistics}

Normal distributions of parametric variables were examined by using the Shapiro-Wilk W test for normality. For statistical analyses, TC, LDL-C, HDL-C and TG levels were log transformed to normalize distribution of the levels. Non-transformed data are however presented in tables and text (as mean \pm standard error) with all the p-values related to logarithmically transformed data. Chi-square analysis or Fisher exact test were used to compare discrete parameters. We used multivariate analysis of variance (procedure GLM for SAS) with genotype group (APOB + , LDLR+, APOB(LDLR-), sex and age as covariates to compare lipid and apolipoprotein levels between the groups with subsequent Tukey post hoc test for multiple comparisons of withingroup means. P value $<0.05$ was considered as statistically significant. All computations were carried out with the SAS vs. 9.3 and STATA vs. 9.0. The compound heterozygous proband was excluded from statistical analyses of clinical and biochemical data.

\section{Ethic committee approval}

The present study was approved by the institutional Ethics Committees (Institute of Preventive and Clinical Medicine of the Slovak Medical University, University Hospital of Bratislava and National Institute of Endocrinology and Diabetology in Lubochna, Slovakia) and all of the participants (or their parents in probands $<18$ years old) signed an informed consent for the genotype and phenotype analyses.

\section{Results}

\section{Genotypes of the patients with $\mathrm{FH}$}

The $A P O B$ mutation p.Arg3527Gln was detected in 14 out of 235 probands $(6 \%)$ and 2 family relatives out of 124 . In the remaining probands, we have identified 89 (37.9\%) with LDLR mutation (Table 1). Out of their 122 family relatives 75 had an $L D L R$ mutation. One of the positive probands was a compound heterozygote for two mutations in LDLR gene (p.Arg416Trp/p.Gly592Glu), this is the first case of genetically confirmed compound heterozygote $\mathrm{FH}$ patient in Slovakia.

The mutational spectrum in the $L D L R$ gene consisted of 54 different mutations, from them 40 were substitutions, 9 small insertions and deletions and 5 large rearrangements (Table 1). No regional mutational hot-spots were observed, but the most frequently detected mutation p.Gly592Glu, was found in 12 probands $(13.5 \%)$ and 8 family relatives.

\section{Novel LDLR mutations}

Nine of the $L D L R$ mutations were novel. Five of these mutations were single nucleotide substitutions leading to single amino acid (AA) change (p.Asp90Glu, p.Asp136Tyr, p.Ser177Pro, p.Gly478Glu, p.Leu680Pro). One novel mutation was a substitution in a conserved splicing site (c.314-2A>G). Last three mutations were insertions/deletions leading to in-frame (p.Lys225_Glu228delinsCysLys) or frame-shift AA change (p.Gly675Trpfs*42, p.Thr832Argfs*3). All novel mutations were submitted to the LOVD FH database (http://databases.lovd.nl/shared/genes/LDLR).

These mutations have not been reported previously and were predicted being pathogenic by SIFT/Provean, PolyPhen2, MutationTaster and, in case of c.314-2A $>$ G, Human Splicing Finder. In silico analyses of the novel $L D L R$ mutations are displayed in the Table 2. Neither of the novel mutations was present in more than 400 ethnically matched chromosomes. Moreover, none of the mutations was present in the 1,000 Genomes Project, or in more than 6,500 individuals screened in NHLBI Exome Sequencing Project. The cosegregation of the novel variants with elevated LDL-C or TC levels in family pedigrees predicted their pathogenicity (data not shown).

In one proband a novel variant p.Asp170Glu in LDLR gene was identified. In silico analyses of this variant did not predict the pathogenicity, in addition this variant did not cosegregate with elevated LDL-C levels in proband's family.

\section{Genotype-phenotype correlations}

TC and LDL-C levels in probands with heterozygous $L D L R$ mutation (LDLR + ) were significantly higher compared to both $A P O B$ mutation unrelated carriers $(\mathrm{p}<0.05)$ and probands with no mutation detected in studied genes (APOB-/LDLR-) $(\mathrm{p}<0.0001)$. However there were no significant differences between $\mathrm{APOB}+$ probands and APOB-/LDLR-probands in TC and LDL-C levels. No significant changes in HDL-C and TG levels were observed between particular groups (Table 3 ). In family relatives carrying the $A P O B$ or $L D L R$ mutation, no significant differences in phenotype (i.e. total, LDL, HDL cholesterol, or triglycerides) compared to the probands were observed (data not shown). The compound heterozygous proband has manifested untreated TC level $15 \mathrm{mmol} / \mathrm{l}$, had an evidence of tendon xanthoma and suffered from MI at the age of 48 years. 
Table 1. Spectrum of mutations and novel variants in $L D L R$ gene found in Slovak patients with $\mathrm{FH}$.

\begin{tabular}{|c|c|c|c|c|c|c|}
\hline $\begin{array}{l}\text { Exon/ } \\
\text { Intron }\end{array}$ & cDNA position & $\begin{array}{l}\text { Protein } \\
\text { position }\end{array}$ & Domain & Frequency & $\begin{array}{c}\text { No of } \\
\text { probands }\end{array}$ & $\begin{array}{c}\text { No of } \\
\text { relatives }\end{array}$ \\
\hline Prom & c. $-149 \mathrm{C}>\mathrm{A}$ & & Signal & 1.11 & 1 & 0 \\
\hline $\begin{array}{l}\text { Ex } \\
12\end{array}$ & c. $1-?, 190+?$ del & Exon 1_2del & $\begin{array}{c}\text { Signal-- } \\
\text { ligand-binding }\end{array}$ & 1.11 & 1 & 0 \\
\hline$\overline{\mathrm{Ex}} 1$ & c. $58 \mathrm{G}>\mathrm{A}$ & Gly20Arg & Signal & 1.11 & 1 & 0 \\
\hline Int 1 & c. $68-2 \mathrm{~A}>\mathrm{T}$ & & Signal & 4.44 & 4 & 1 \\
\hline $\begin{array}{l}\text { Ex } \\
2 \_5\end{array}$ & c.68-?_817+?dup & Exon 2_5dup & ligand-binding & 2.22 & 2 & 1 \\
\hline$\overline{\mathrm{Ex}} 2$ & c. $81 \mathrm{C}>\mathrm{G}$ & Cys27Trp & ligand-binding & 1.11 & 1 & 1 \\
\hline Ex 2 & c. $100 \mathrm{~T}>\mathrm{G}$ & Cys34Gly & ligand-binding & 3.33 & 3 & 4 \\
\hline Ex 2 & c. $131 \mathrm{G}>\mathrm{A}$ & Trp44* & ligand-binding & 1.11 & 1 & 2 \\
\hline Int 2 & c.191-1 G>A & & ligand-binding & 1.11 & 1 & 1 \\
\hline Ex 3 & c.191-?_313+?del & Exon 3del & ligand-binding & 1.11 & 1 & 0 \\
\hline Ex 3 & c. $27 \overline{0} \mathrm{~T}>\mathrm{G}$ & Asp90Glu & ligand-binding & 1.11 & 1 & 2 \\
\hline Int 3 & c. $313+2$ dupT & & ligand-binding & 1.11 & 1 & 0 \\
\hline Int 3 & c. $314-2 \quad A>G$ & & ligand-binding & 2.22 & 2 & 2 \\
\hline $\begin{array}{l}\text { Ex } \\
4 \_8\end{array}$ & c.314-?_1186+?dup & Exon 4_8dup & $\begin{array}{l}\text { ligand-binding - } \\
\text { EGF precursor }\end{array}$ & 2.22 & 2 & 0 \\
\hline Ex 4 & c. $406 \mathrm{G}>\mathrm{T}$ & Asp136Tyr & ligand-binding & 1.11 & 1 & 0 \\
\hline Ex 4 & c. $510 \mathrm{C}>\mathrm{A}^{*}$ & Asp170Glu* & ligand-binding & 1.11 & 1 & 1 \\
\hline Ex 4 & c. $529 \mathrm{~T}>\mathrm{C}$ & Ser177Pro & ligand-binding & 2.22 & 2 & 3 \\
\hline Ex 4 & c. $530 \mathrm{C}>\mathrm{T}$ & Ser177Leu & ligand-binding & 1.11 & 1 & 0 \\
\hline Ex 4 & c. $626 \mathrm{G}>\mathrm{A}$ & Cys209Tyr & ligand-binding & 1.11 & 1 & 1 \\
\hline Ex 4 & c.654_656delTGG & Gly219del & ligand-binding & 1.11 & 1 & 0 \\
\hline Ex 4 & c. $\overline{6} 62 \mathrm{~A}>\mathrm{G}$ & Asp221Gly & ligand-binding & 1.11 & 1 & 0 \\
\hline Ex 4 & c. $666 \mathrm{C}>\mathrm{A}$ & Cys $222^{*}$ & ligand-binding & 1.11 & 1 & 0 \\
\hline Ex 4 & $\begin{array}{c}\text { c.673_682del10ins } \\
\text { TGCA }\end{array}$ & Lys225_Glu228delinsCysLys & ligand-binding & 1.11 & 1 & 0 \\
\hline Ex 5 & c. $798 \mathrm{~T}>\mathrm{A}$ & Asp266Glu & ligand-binding & 3.33 & 3 & 7 \\
\hline Ex 6 & c. $862 \mathrm{G}>\mathrm{T}$ & Glu288* & ligand-binding & 1.11 & 1 & 4 \\
\hline Ex 7 & c. $949 \mathrm{G}>\mathrm{T}$ & Glu317* & EGF precursor & 1.11 & 1 & 0 \\
\hline Ex 7 & c. $953 \mathrm{G}>\mathrm{T}$ & Cys318Phe & EGF precursor & 1.11 & 1 & 4 \\
\hline Ex 7 & c. 970 delG & Gly324Alafs*46 & EGF precursor & 1.11 & 1 & 0 \\
\hline Ex 7 & c. $1019 \mathrm{G}>\mathrm{A}$ & Cys340Tyr & EGF precursor & 3.33 & 3 & 3 \\
\hline Ex 7 & c. $1027 \mathrm{G}>\mathrm{A}$ & Gly343Ser & EGF precursor & 2.22 & 2 & 2 \\
\hline Ex 7 & c. $1056 \mathrm{C}>\mathrm{G}$ & Cys352Trp & EGF precursor & 2.22 & 2 & 1 \\
\hline Ex 8 & c. $1117 \mathrm{G}>\mathrm{T}$ & Gly373Cys & EGF precursor & 1.11 & 1 & 0 \\
\hline Ex 8 & c. $1129 \mathrm{~T}>\mathrm{C}$ & Cys377Arg & EGF precursor & 2.22 & 2 & 1 \\
\hline Ex 8 & c. $1130 \mathrm{G}>\mathrm{A}$ & Cys377Tyr & EGF precursor & 1.11 & 1 & 0 \\
\hline Int 8 & c. $1187-10 \mathrm{G}>\mathrm{A}$ & & EGF precursor & 1.11 & 1 & 0 \\
\hline Ex 9 & c. $1246 \mathrm{C}>\mathrm{T}$ & Arg416Trp & EGF precursor & 5.55 & 5 & 7 \\
\hline Ex 9 & c.1272_1273ins96 & Pro424_Asn425ins32 & EGF precursor & 1.11 & 1 & 6 \\
\hline Ex 9 & c. $12 \overline{285} \mathrm{G}>\mathrm{A}$ & Vā1429Met & EGF precursor & 1.11 & 1 & 0 \\
\hline Ex 9 & c. $1291 \mathrm{G}>\mathrm{A}$ & Ala431Thr & EGF precursor & 2.22 & 2 & 1 \\
\hline Ex 10 & c. $1414 \mathrm{G}>\mathrm{T}$ & Asp472Tyr & EGF precursor & 3.33 & 3 & 3 \\
\hline Ex 10 & c. $1433 \mathrm{G}>\mathrm{A}$ & Gly478Glu & EGF precursor & 1.11 & 1 & 3 \\
\hline Ex 10 & c. $1516 \_1562 \mathrm{del}$ & Val506delfs" 14 & EGF precursor & 1.11 & 1 & 0 \\
\hline Ex 12 & c. $1775 \mathrm{G}>\mathrm{A}$ & Gly592Glu & EGF precursor & 13.33 & 12 & 8 \\
\hline Ex 12 & c. $1834 \mathrm{G}>\mathrm{T}$ & Ala612Ser & EGF precursor & 1.11 & 1 & 0 \\
\hline $\begin{array}{l}\text { Ex } \\
13 \_18\end{array}$ & c.1846-?_2583+?del & Exon 13_18del & $\begin{array}{l}\text { EGF precursor - } \\
\text { cytoplasmic }\end{array}$ & 1.11 & 1 & 0 \\
\hline $\mathrm{Ex} 13$ & c. $1864 \mathrm{G}>\mathrm{A}$ & Asp622Asn & EGF precursor & 1.11 & 1 & 2 \\
\hline Ex 13 & c.1871_1873delTCA & Ile624del & EGF precursor & 1.11 & 1 & 3 \\
\hline Ex 14 & c. $\overline{1999} \mathrm{~T}>\mathrm{C}$ & Cys667Arg & EGF precursor & 1.11 & 1 & 0 \\
\hline Ex 14 & c. 2022 dupT & Gly675Trpfs 42 & EGF precursor & 1.11 & 1 & 1 \\
\hline Ex 14 & c. $2023 \mathrm{G}>\mathrm{A}$ & Gly675Ser & EGF precursor & 1.11 & 1 & 0 \\
\hline Ex 14 & c. $2039 \mathrm{~T}>\mathrm{C}$ & Leu680Pro & transmembrane & 1.11 & 1 & 1 \\
\hline Ex 14 & c. $2096 \mathrm{C}>\mathrm{T}$ & Pro699Leu & transmembrane & 3.33 & 3 & 0 \\
\hline Ex 16 & c. $2389 \mathrm{G}>\mathrm{A}$ & Val797Met & transmembrane & 1.11 & 1 & 0 \\
\hline Ex 17 & c. $2479 \mathrm{G}>\mathrm{A}$ & Val827Ile & cytoplasmic & 1.11 & 1 & 0 \\
\hline Ex 17 & c. $2495 \mathrm{delCA}$ & Thr832Argfs*3 & cytoplasmic & 1.11 & 1 & 0 \\
\hline
\end{tabular}

* rare polymorphism 
Table 2. In silico analysis of the novel missense $L D L R$ variants.

\begin{tabular}{|c|c|c|c|c|c|c|c|c|}
\hline $\begin{array}{l}\text { Exon/ } \\
\text { Intron }\end{array}$ & $\begin{array}{c}\text { cDNA } \\
\text { position }\end{array}$ & Protein position & SIFT & Polyphen2 & $\begin{array}{l}\text { Mutation } \\
\text { Taster }\end{array}$ & Provean & $\begin{array}{c}\text { Human } \\
\text { Splicing } \\
\text { Finder }\end{array}$ & $\begin{array}{c}\text { Variant } \\
\text { classification }\end{array}$ \\
\hline Ex 3 & c. $270 \mathrm{~T}>\mathrm{G}^{*}$ & p.Asp90Glu* & damaging & $\begin{array}{l}\text { probably } \\
\text { damaging }\end{array}$ & $\begin{array}{l}\text { disease } \\
\text { causing }\end{array}$ & deleterious & N/A & 4 \\
\hline Int 3 & c. $314-2 \mathrm{~A}>\mathrm{G}$ & & N/A & N/A & N/A & N/A & $\begin{array}{l}\text { splice } \\
\text { site } \\
\text { broken }\end{array}$ & 4 \\
\hline Ex 4 & c. $406 \mathrm{G}>\mathrm{T}$ & p.Asp136Tyr & damaging & $\begin{array}{l}\text { probably } \\
\text { damaging }\end{array}$ & $\begin{array}{l}\text { disease } \\
\text { causing }\end{array}$ & deleterious & N/A & 4 \\
\hline Ex 4 & c. $510 \mathrm{C}>\mathrm{A}$ & p.Asp170Glu & tolerated & benign & $\begin{array}{l}\text { disease } \\
\text { causing }\end{array}$ & neutral & N/A & 2 \\
\hline Ex 4 & c.529 T>C & p.Ser177Pro & damaging & $\begin{array}{l}\text { probably } \\
\text { damaging }\end{array}$ & $\begin{array}{l}\text { disease } \\
\text { causing }\end{array}$ & deleterious & N/A & 4 \\
\hline Ex 4 & $\begin{array}{c}\text { c.673_682del } \\
\text { 10insTGCA }\end{array}$ & $\begin{array}{c}\text { p.Lys } 225 \text { Glu228 } \\
\text { delinsCysLys }\end{array}$ & N/A & N/A & $\begin{array}{l}\text { disease } \\
\text { causing }\end{array}$ & deleterious & N/A & 4 \\
\hline Ex 10 & c. $1433 \mathrm{G}>\mathrm{A}$ & p.Gly478Glu & damaging & $\begin{array}{l}\text { probably } \\
\text { damaging }\end{array}$ & $\begin{array}{l}\text { disease } \\
\text { causing }\end{array}$ & deleterious & N/A & 4 \\
\hline Ex 14 & c. $2039 \mathrm{~T}>\mathrm{C}$ & p.Leu680Pro & damaging & $\begin{array}{l}\text { probably } \\
\text { damaging }\end{array}$ & $\begin{array}{l}\text { disease } \\
\text { causing }\end{array}$ & deleterious & N/A & 4 \\
\hline
\end{tabular}

N/A not applicable, Variant classification according to EuroGentest guidelines: 5-pathogenic, 4-likely pathogenic, 3-variant of unknown significance (VUS), 2-likely benign, 1-benign; *similar variant with different nucleotide substitution c.270 T>A (p.Asp90Glu) was already published.

Table 3. Phenotype characterization of the heterozygous FH probands in Slovakia.

\begin{tabular}{|c|c|c|c|c|c|c|c|}
\hline Characteristics & APOB+ & $\mathbf{N}$ & LDLR+ & $\mathbf{N}$ & $\begin{array}{l}\text { APOB- } \\
\text { /LDLR- }\end{array}$ & $\mathbf{N}$ & $\mathbf{P}$ \\
\hline Female/Male & $12 / 2$ & 14 & $44 / 44$ & 88 & $89 / 43$ & 132 & \\
\hline Age & $27.1 \pm 4.6^{\mathrm{a}}$ & 14 & $30.6 \pm 1.8^{\mathrm{a}}$ & 88 & $39.5 \pm 1.4^{\mathrm{b}}$ & 132 & $<0.0001$ \\
\hline TC $(\mathrm{mmol} / \mathrm{l})$ & $8.3 \pm 0.3^{\mathrm{a}}$ & 14 & $9.3 \pm 0.2^{\mathrm{b}}$ & 85 & $8.4 \pm 0.1^{\mathrm{a}}$ & 130 & $<0.0001$ \\
\hline$L D L-C(\mathrm{mmol} / \mathrm{l})$ & $6.0 \pm 0.3^{\mathrm{a}}$ & 13 & $7.0 \pm 0.1^{\mathrm{b}}$ & 85 & $5.9 \pm 0.1^{\mathrm{a}}$ & 124 & $<0.0001$ \\
\hline$H D L-C(\mathrm{mmol} / \mathrm{l})$ & $1.4 \pm 0.1^{\mathrm{a}}$ & 13 & $1.5 \pm 0.0^{\mathrm{a}}$ & 77 & $1.5 \pm 0.0^{\mathrm{a}}$ & 116 & NS \\
\hline$T G(\mathrm{mmol} / \mathrm{l})$ & $1.5 \pm 0.3^{\mathrm{a}}$ & 13 & $1.4 \pm 0.1^{\mathrm{a}}$ & 78 & $1.8 \pm 0.1^{\mathrm{a}}$ & 118 & NS \\
\hline$B M I\left(\mathrm{~kg} / \mathrm{m}^{2}\right)$ & $24.3 \pm 1.1^{\mathrm{a}}$ & 10 & $25.4 \pm 0.4^{\mathrm{a}}$ & 66 & $25.7 \pm 0.3^{\mathrm{a}}$ & 113 & NS \\
\hline $\begin{array}{l}H L P \text { in } 1^{s t} \text { degree } \\
\text { relative }\end{array}$ & $92.9 \%$ & 14 & $93.0 \%$ & 86 & $84.7 \%$ & 131 & NS \\
\hline$C V D$ in patient $/ 1^{s t}$ & & & & & & & \\
\hline $\begin{array}{l}\text { degree relative } \\
<65 \text { years }\end{array}$ & $28.6 \%$ & 14 & $36.1 \%$ & 83 & $41.9 \%$ & 124 & NS \\
\hline Tendon xanthomas & $14.3 \%$ & 14 & $18.2 \%$ & 88 & $6.1 \%$ & 132 & $<0.05$ \\
\hline
\end{tabular}

Values are expressed as mean $\pm \mathrm{SE}$ (age and sex adjusted), $\mathrm{P}$ - related to logarithmically transformed data (GLM), values without a common superscript ${ }^{(a, b)}$ are significantly different (Tukey test, see results section for $p$-values), NS - non significant.

\section{Fulfillment of clinical criteria}

All probands (APOB+, LDLR+, APOB-/

LDLR-) fulfilled the basic criterion of LDL-C or/and TC above $95^{\text {th }}$ percentile for age and gender. High percentage of probands had the evidence of hyperlipoproteinemia in the first degree family relative $(84 \%-93 \%)$. The personal/relative evidence of CVD fulfilled $28 \%-42 \%$. Only $6 \%-18 \%$ (according to the genotype groups) probands had evidence of tendon xanthomas (Table 3).
Probands with tendon xanthomas suffered more frequently from CVD below the age of 65 years than probands without tendon xanthomas (26.9\% vs. $5.8 \%$; $\mathrm{P}<0.05)$.

\section{Discussion}

This is the first study assessing the molecular genetic background of autosomal dominant hypercholesterolemia due to $L D L R$ gene mutations, 
including the first report of genetically confirmed compound heterozygote patient in Slovakia. Of the 235 probands we have identified $103(43.8 \%)$ probands with mutation in one of the genes studied.

The most frequent mutation in $A P O B$ gene p.Arg3527Gln was identified in 14 probands $(6.0 \%)$ and 2 family relatives out of 124 . The frequency of the p.Arg3527Gln mutation in this study is in agreement with published data from neighboring countries (Czech republic $11.8 \%$, Poland $6.6 \%$, Austria $4.7 \%$ and Hungary $5.5 \%$ ) (Tichy et al. 2012, Chmara et al. 2010, Widhalm et al. 2007, Kalina et al. 2001) and also in agreement with our previous study (9.7\%) (Gasparovic et al. 2007).

In the $L D L R$ gene, we have identified a mutation in 89 probands $(37.9 \%)$ and 75 family relatives. The mutational spectrum revealed 54 different mutations including 9 novel variants. For the clinical suspicion of $\mathrm{FH}$, it is critical to assess whether the novel variant is pathogenic or not, therefore set of criteria need to be used for pathogenicity evaluation. The first criterion is the co-segregation of $L D L R$ variant with clinical phenotype. The second criterion is based upon the in silico analyses. All variants were predicted as pathogenic (Table 2). In addition, one novel variant p.Asp170Glu was identified in one proband. This novel variant was predicted by Polyphen 2 as benign and by SIFT/Provean as neutral. Moreover, the phenotype-genotype cosegregation in the family has not proven the pathogenicity, therefore we conclude that the variant p.Asp170Glu in the LDLR gene is a rare polymorphism.

From 54 different mutations, 40 mutations were substitutions, 9 small insertions (up to $100 \mathrm{bp}$ ) and 5 large rearrangements (Table 1). The identified mutations occurred in almost all exons except the exons 11, 15 and 18. Most frequently, mutations were detected in exon 4, which is the longest exon of the LDLR. Nevertheless, the broad range of mutation spectrum highlighted the importance of analyzing the whole gene during molecular diagnosis in order to identify all potential mutations.

In some populations only a few mutations of the $L D L R$ due to the founder effect predominate, in Icelanders (Gudnason et al. 1997), Ashkenazi and Sephardic Jews (Meiner et al. 1991) (Leitersdorf et al. 1993) and Finns (Koivisto et al. 1995, Aalto-Setala et al. 1989). On the other hand, the heterogeneous mutational spectrum of $L D L R$ was published in most countries (Table 4). The most common mutation in Slovakia was p.Gly592Glu (13.5\% of all LDLR positive probands), which is in agreement also with findings in the Czech Republic and Poland, where this mutation accounts for $19 \%$ and $22 \%$ Czech and Polish FH cases, respectively (Tichy et al. 2012, Chmara et al. 2010). The second most common mutation in this study p.Arg416Trp, is also the third most common mutation in the Czech Republic. In addition, the second most common mutation identified in Czech Republic p.Asp266Glu was also one of the most common mutations in Germany and Austria; however in Slovakia we found this mutation only in $3 \%$ of positive probands. These findings indicate similar mutational spectrum of the $L D L R$ in the Central Europe region. On the contrary, the geographically distant countries show different mutation spectrum in comparison to the countries of Central Europe (Table 4).

In concordance with other studies, the probands with mutation in the $L D L R$ gene have higher age-adjusted TC and LDL-C levels compared to APOB+ and APOB/LDLR- probands (Tichy et al. 2012) (Table 3). No significant difference was observed in HDL-C and TG levels between the three groups studied.

Concerning the TG levels, the data in literature are not consistent. No differences in TG levels were reported in large studies (Fouchier et al. 2005). On the other hand, high levels of TG in LDLR- compared to LDLR+ patients were observed in other studies (van AalstCohen et al. 2006, Tichy et al. 2012). In a previous study from Slovakia, APOB + patients had significantly lower TG levels than other patients with clinical diagnosis of FH (Gasparovic et al. 2007). We cannot exclude that certain proportion of subjects with clinical diagnosis of FH in our previous study were in fact affected by familial combined hyperlipidemia $(\mathrm{FCH})$ that in individual patients can manifest with similar phenotype as in FH. In absence of tendon xanthomas in a patient without sufficient family history of lipid phenotypes in relatives, it might be difficult to distinguish $\mathrm{FH}$ from $\mathrm{FCH}$.

The most serious consequence of $\mathrm{FH}$ is the increased risk of cardiovascular disease. The occurrence of CVD in probands/relatives was between (37-42\%) and the evidence of tendon xanthomas was highest in LDLR+, followed by APOB + and the lowest occurrence was in APOB-/LDLR- group. However, probands with tendon xanthomas suffered more frequently from CVD below the age of 65 years than probands without tendon xanthomas $(26.9 \%$ vs. $5.8 \% ; \mathrm{P}<0.05)$. These findings are in concordance with other studies, where patients with tendon xanthomas had higher risk of CVD (Oosterveer et al. 2009, Civeira et al. 2005). 
Table 4. Comparison of studies focused on the genotype of the FH patients.

\begin{tabular}{|c|c|c|c|c|c|c|c|}
\hline Locality & Country & $\begin{array}{l}\text { Diagnostic } \\
\text { criteria }\end{array}$ & $\begin{array}{l}\text { Number } \\
\text { of } \\
\text { probands }\end{array}$ & $\begin{array}{c}\text { Number of } \\
\text { detected } \\
\text { mutations } \\
\text { in } L D L R\end{array}$ & $\begin{array}{c}\text { Most common } \\
\text { mutations } \\
\text { (frequency \%) }\end{array}$ & $\begin{array}{l}\text { Frequency } \\
\text { of the } \\
\text { most } \\
\text { frequent } \\
\text { mutations } \\
\text { out of all } \\
\text { mutations }\end{array}$ & Ref. \\
\hline \multirow[t]{5}{*}{$\begin{array}{l}\text { Central } \\
\text { Europe }\end{array}$} & Slovakia & $\begin{array}{l}\text { LDL-C 95th } \\
\text { percentile }+ \\
\text { HCH in } \\
\text { family }\end{array}$ & 235 & 54 & $\begin{array}{l}\text { p.Gly592Glu (13.3) } \\
\text { p.Arg416Trp (5.6) } \\
\text { c. } 68-2 \mathrm{~A}>\mathrm{T}(4.4)\end{array}$ & 23.3 & This study \\
\hline & $\begin{array}{c}\text { Czech } \\
\text { Republic }\end{array}$ & $\begin{array}{l}\text { LDL-C 95th } \\
\text { percentile }+ \\
\text { family history }\end{array}$ & 2239 & 127 & $\begin{array}{l}\text { p.Gly592Glu (19.3) } \\
\text { p.Asp266Glu (16.4) } \\
\text { p.Arg416Trp (4.1) }\end{array}$ & 39.8 & $\begin{array}{l}\text { (Tichy et } \\
\text { al. 2012) }\end{array}$ \\
\hline & Poland & DLCN & 378 & 71 & $\begin{array}{l}\text { p.Gly592Glu (22.5) } \\
\text { Exon4_8dup (9.5) } \\
\text { p.Asp221Gly (5.3) }\end{array}$ & 37.3 & $\begin{array}{l}\text { (Chmara et } \\
\text { al. 2010) }\end{array}$ \\
\hline & Germany & $\begin{array}{l}\text { LDL-C 95th } \\
\text { percentile }+ \\
\text { positive HCH } \\
\text { in family }\end{array}$ & 100 & 37 & $\begin{array}{l}\text { p.Glu228* (10.2) } \\
\text { p.Asp266Glu (8.2) } \\
\text { c. } 313+2 T>C(6.1)\end{array}$ & 24.5 & $\begin{array}{l}\text { (Nauck et } \\
\text { al. 2001) }\end{array}$ \\
\hline & Austria & MedPed & $263 *$ & 47 & $\begin{array}{l}\text { p.Asp266Glu(11.1) } \\
\text { p.Asp221Gly (5.6) } \\
\text { p.Asp178Glu (4.6) } \\
\text { p.Val506delfs"14 (4.6) }\end{array}$ & 25.9 & $\begin{array}{l}\text { (Widhalm } \\
\text { et al. 2007) }\end{array}$ \\
\hline \multirow[t]{4}{*}{$\begin{array}{l}\text { Western } \\
\text { Europe }\end{array}$} & $\begin{array}{l}\text { Great } \\
\text { Britain }\end{array}$ & $\begin{array}{l}\text { Simon } \\
\text { Broom }\end{array}$ & 272 & 54 & $\begin{array}{c}\text { p.Glu101Lys (6.6) } \\
\text { p.Trp87Gly (3.3) } \\
\text { c.313+1G>A (3.3) } \\
\text { p.Asp227Glyfs"12 (3.3) } \\
\text { p.Asp227Glu (3.3) } \\
\text { p.Glu374fs" } 8 \text { (3.3) } \\
\text { p.Pro685Leu (3.3) }\end{array}$ & 26.4 & $\begin{array}{l}\text { (Futema et } \\
\text { al. 2013) }\end{array}$ \\
\hline & Netherlands & DLCN & 1641 & 148 & $\begin{array}{c}\text { p.Asn543His } / \mathrm{c} .2393 \mathrm{del} 9(19) \\
\text { c. } 1359-1 \mathrm{G}>\mathrm{A}(12.2) \\
\text { c. } 313+1 \mathrm{G}>\mathrm{A} / \mathrm{C}+ \\
\text { c. } 313+2 \mathrm{~T}>\mathrm{C}(10.5) \\
\text { p.Trp44* }(6.2)\end{array}$ & 47.9 & $\begin{array}{l}\text { (Fouchier } \\
\text { et al. 2001) }\end{array}$ \\
\hline & Spain & DLCN & 476 & 116 & $\begin{array}{c}\text { c. } 313+1 \mathrm{G}>\mathrm{C}(8.5) \\
\text { p.Gln } 92 \mathrm{Glu}(8.2) \\
\text { p.Gln } 154^{*}(5.2) \\
\text { p.Gln } 448^{*}(5.2)\end{array}$ & 27.1 & $\begin{array}{l}\text { (Mozas et } \\
\text { al. 2004) }\end{array}$ \\
\hline & Italy & $\begin{array}{c}\text { DLCN } \\
\text { (modified) }\end{array}$ & 1070 & 237 & $\begin{array}{c}\text { p.Asp221Gly (9.2) } \\
\text { p.Gly549Asp (8.5) } \\
\text { p.Val523Met (6.6) } \\
\text { p.Gln474Hisfs"63 (5.6) }\end{array}$ & 29.8 & $\begin{array}{l}\text { (Bertolini } \\
\text { et al. 2013) }\end{array}$ \\
\hline \multirow[t]{3}{*}{ Other } & Greece & $\begin{array}{l}\text { Simon } \\
\text { Broom } \\
\text { (modified) }\end{array}$ & 262 & 26 & $\begin{array}{l}\text { p.Gly549Asp (30.7) } \\
\text { p.Ser286Arg (17.9) } \\
\text { p.Cys27Trp (12.9) } \\
\text { p.Val429Met (12.1) }\end{array}$ & 73.6 & $\begin{array}{c}\text { (Mollaki et } \\
\text { al. 2014) }\end{array}$ \\
\hline & Bulgary & $\begin{array}{c}\mathrm{TC} \\
>8.5 \mathrm{mmol} / 1\end{array}$ & 45 & 5 & $\begin{array}{c}\text { p.Ser265Arg (37.5) } \\
\text { p.Ser102Thr (25) }\end{array}$ & 62.5 & $\begin{array}{l}\text { (Mihaylov } \\
\text { et al. 2004) }\end{array}$ \\
\hline & $\begin{array}{l}\text { Western } \\
\text { Australia }\end{array}$ & DLCN & 343 & 84 & $\begin{array}{l}\text { c. } 313+1 \mathrm{G}>\mathrm{A}(5) \\
\text { p.Cys184Tyr (3.3) } \\
\text { p.Arg350* }(3.3)\end{array}$ & 11.7 & $\begin{array}{c}\text { (Hooper et } \\
\text { al. 2012) }\end{array}$ \\
\hline
\end{tabular}

* number of probands and relatives; DLCN = Dutch Lipid Clinic Network criteria. 
The similar clinical manifestation of CVD could be the result of other risk factors than LDL-C levels like smoking, obesity, diabetes, other lipoprotein phenotypes or involvement of other gene variants related to lipid metabolism (data not available). Selection bias cannot be also excluded.

The APOB-/LDLR- group of probands had significantly higher age than positive APOB + and LDLR+ patients. However, we cannot exclude that hypercholesterolemia in a substantial proportion of APOB-/LDLR- subjects is in fact related to polygenic background and therefore, their phenotype could be manifested in later age compared to monogenic subjects, where high cholesterol is evident from birth. Similar finding was observed in a Czech FH population (Tichy et al. 2012).

Moreover, the phenotype of the compound heterozygous patient was less severe than the phenotype of patients with $L D L R$-negative homozygous mutations. This finding is consistent with the observation form other studies (Cuchel et al. 2014).

\section{Strengths and Limitations}

Strength of this study is based on the participation of several specialized outpatient departments (including several pediatric centers) from several parts of Slovakia and the complex DNA analysis of whole $L D L R$ gene. The limitation of our study could be relatively small number of participants according to the estimated $\mathrm{FH}$ prevalence.

\section{Implication for clinicians}

Knowledge of the etiology of hypercholesterolemia is very important also from the perspective of clinical medicine. Genetic confirmation of FH in proband simplifies the diagnostic process in proband's family and defines the risk of inheriting $\mathrm{FH}$ for the offspring. Confirmation of the $\mathrm{FH}$ etiology is particularly important in children, as patients with mutation, severe phenotype and family history of premature CVD, should be medically treated already in childhood or adolescence.

FH criteria used in our study were modified from van Aalst-Cohen, which are similar to Simon Broome criteria, however they are using stricter TC and LDL-C levels adjusted for age and gender. We have also modified the criteria due to relatively low availability and reliability of clinical information from first degree relatives. We are aware that this can lead to lower sensitivity, however, $43.8 \%$ detection rate of a genetic defect in our study is similar to other populations (Tichy et al. 2012, Palacios et al. 2012).

\section{Conclusions}

This is the first study assessing the molecular genetic background of autosomal dominant hypercholesterolemia due to $L D L R$ gene mutations, including the first report of genetically confirmed compound heterozygote in Slovakia. The broad mutational spectrum detected in $L D L R$ gene points to the importance of sequencing the whole $L D L R$ gene in patients with a strong clinical suspicion of $\mathrm{FH}$.

\section{Conflict of Interest}

There is no conflict of interest.

\section{Acknowledgements}

We would like to thank the Slovak FH study group (Karin Balintova, Ingrid Buganova, Vladimir Bzduch, Lukas Kudera, Ludmila Potocnakova, Jana Sirotiakova, Martina Sojkova, Jana Saligova, Adriana Simkova, Alica Valachova and Daniela Virgova) and to Alica Mitkova for technical support. This work was supported by (Transendogen/26240220051) and the Research \& Development Operational Program (to IK and DG).

\section{References}

AALTO-SETALA K, HELVE E, KOVANEN PT, KONTULA K: Finnish type of low density lipoprotein receptor gene mutation (FH-Helsinki) deletes exons encoding the carboxy-terminal part of the receptor and creates an internalization-defective phenotype. J Clin Invest 84: 499-505, 1989.

AUSTIN MA, HUTTER CM, ZIMMERN RL, HUMPHRIES SE: Genetic causes of monogenic heterozygous familial hypercholesterolemia: a HuGE prevalence review. Am J Epidemiol 160: 407-420, 2004.

BERTOLINI S, PISCIOTTA L, RABACCHI C, CEFALU AB, NOTO D, FASANO T, SIGNORI A, FRESA R, AVERNA M, CALANDRA S: Spectrum of mutations and phenotypic expression in patients with autosomal dominant hypercholesterolemia identified in Italy. Atherosclerosis 227: 342-348, 2013. 
CIVEIRA F, CASTILLO S, ALONSO R, MERINO-IBARRA E, CENARRO A, ARTIED M, MARTIN-FUENTES P, ROS E, POCOVI M, MATA P.: Tendon xanthomas in familial hypercholesterolemia are associated with cardiovascular risk independently of the low-density lipoprotein receptor gene mutation. Arterioscler Thromb Vasc Biol 25: 1960-1965, 2005.

CUCHEL M, BRUCKERT E, GINSBERG HN, RAAL FJ, SANTOS RD, HEGELE RA, KUIVENHOVEN JA, NORDESTGAARD BG, DESCAMPS OS, STEINHAGEN-THIESSEN E: Homozygous familial hypercholesterolaemia: new insights and guidance for clinicians to improve detection and clinical management. A position paper from the Consensus Panel on Familial Hypercholesterolaemia of the European Atherosclerosis Society. Eur Heart J 35: 2146-2157, 2014.

FOUCHIER SW, DEFESCHE JC, UMANS-ECKENHAUSEN MW, KASTELEIN JP: The molecular basis of familial hypercholesterolemia in The Netherlands. Hum Genet 109: 602-615, 2001.

FOUCHIER SW, KASTELEIN JJ, DEFESCHE JC: Update of the molecular basis of familial hypercholesterolemia in The Netherlands. Hum Mutat 26: 550-556, 2005.

FREIBERGER T, CESKA R: [Is familial hypercholesterolemia under control in the Czech Republic?]. Vnitr Lek 53: 703-705, 707-708, 2007.

FUTEMA M, WHITTALL RA, KILEY A, STEEL LK, COOPER JA, BADMUS E, LEIGH SE, KARPE F, NEIL HA, SIMON BROOME REGISTER GROUP: Analysis of the frequency and spectrum of mutations recognised to cause familial hypercholesterolaemia in routine clinical practice in a UK specialist hospital lipid clinic. Atherosclerosis 229: 161-168, 2013.

GASPAROVIC J, BASISTOVA Z, FABRYOVA L, WSOLOVA L, VOHNOUT B, RASLOVA K: Familial defective apolipoprotein B-100 in Slovakia: are differences in prevalence of familial defective apolipoprotein B-100 explained by ethnicity? Atherosclerosis 194: e95-e107, 2007.

GOLDSTEIN JL, HOBBS HH, BROWN MS: Familial hypercholesterolemia. In: The Metabolic and Molecular Basis of Inherited Disease. CRIVER CS, BEAUDET AL, SLY WS, BALLE D (eds), McGraw Hill, New York, 2001, pp 2863-2913.

GUDNASON V, SIGURDSSON G, NISSEN H, HUMPHRIES SE: Common founder mutation in the LDL receptor gene causing familial hypercholesterolaemia in the Icelandic population. Hum Mutat 10: 36-44, 1997.

HOOPER AJ, NGUYEN LT, BURNETT JR, BATES TR, BELL DA, REDGRAVE TG, WATTS GF, VAN BOCKXMEER FM: Genetic analysis of familial hypercholesterolaemia in Western Australia. Atherosclerosis 224: 430-434, 2012.

CHATER R, AIT CHIHAB K, RABES J P, VARRET M, CHABRAOUI L, EL JAHIRI Y, ADLOUNI A, BOILEAU C, KETTANI A, EL MESSAL M: Mutational heterogeneity in low-density lipoprotein receptor gene related to familial hypercholesterolemia in Morocco. Clin Chim Acta 373: 62-69, 2006.

CHMARA M, WASAG B, ZUK M, KUBALSKA J, WEGRZYN A, BEDNARSKA-MAKARUK M, PRONICKA E, WEHR H, DEFESCHE JC, RYNKIEWICZ A: Molecular characterization of Polish patients with familial hypercholesterolemia: novel and recurrent LDLR mutations. J Appl Genet 51: 95-106, 2010.

KALINA A, CSASZAR A, CZEIZEL A E, ROMICS L, SZABOKI F, SZALAI C, REIBER I, NEMETH A, STEPHENSON S, WILLIAMS RR: Frequency of the R3500Q mutation of the apolipoprotein B-100 gene in a sample screened clinically for familial hypercholesterolemia in Hungary. Atherosclerosis 154: 247-251, 2001.

KHACHADURIAN AK: Clinical features, diagnosis and frequency of familial hypercholesterolemia. Beitr Infusionsther 23: 26-32, 1988.

KOIVISTO U M, VIIKARI JS, KONTULA K: Molecular characterization of minor gene rearrangements in Finnish patients with heterozygous familial hypercholesterolemia: identification of two common missense mutations (Gly823-->Asp and Leu380-->His) and eight rare mutations of the LDL receptor gene. Am J Hum Genet 57: 789-797, 1995.

LEITERSDORF E, RESHEF A, MEINER V, DANN EJ, BEIGEL Y, VAN ROGGEN FG, VAN DER WESTHUYZEN DR, COETZEE GA: A missense mutation in the low density lipoprotein receptor gene causes familial hypercholesterolemia in Sephardic Jews. Hum Genet 91: 141-147, 1993. 
MEINER V, LANDSBERGER D, BERKMAN N, RESHEF A, SEGAL P, SEFTEL HC, VAN DER WESTHUYZEN DR, JEENAH MS, COETZEE GA, LEITERSDORF E: A common Lithuanian mutation causing familial hypercholesterolemia in Ashkenazi Jews. Am J Hum Genet 49: 443-449, 1991.

MIHAYLOV VA, HORVATH AD, SAVOV AS, KURSHELOVA EF, PASKALEVA ID, GOUDEV AR, STOILOV IR, GANEV VS: Screening for point mutations in the LDL receptor gene in Bulgarian patients with severe hypercholesterolemia. J Hum Genet 49: 173-176, 2004.

MOLLAKI V, PROGIAS P, DROGARI E: Familial Hypercholesterolemia in Greek children and their families: genotype-to-phenotype correlations and a reconsideration of LDLR mutation spectrum. Atherosclerosis 237: 798-804, 2014.

MOZAS P, CASTILLO S, TEJEDOR D, REYES G, ALONSO R, FRANCO M, SAENZ P, FUENTES F, ALMAGRO F, MATA P: Molecular characterization of familial hypercholesterolemia in Spain: identification of 39 novel and 77 recurrent mutations in LDLR. Hum Mutat 24: 187, 2004.

NAUCK MS, KOSTER W, DORFER K, ECKES J, SCHARNAGL H, GIERENS H, NISSEN H, NAUCK MA, WIELAND H, MÄRZ W: Identification of recurrent and novel mutations in the LDL receptor gene in German patients with familial hypercholesterolemia. Hum Mutat 18: 165-166, 2001.

NORDESTGAARD BG, CHAPMAN MJ, HUMPHRIES SE, GINSBERG HN, MASANA L, DESCAMPS OS, WIKLUND O, HEGELE RA, RAAL FJ, DEFESCHE JC: Familial hypercholesterolaemia is underdiagnosed and undertreated in the general population: guidance for clinicians to prevent coronary heart disease: consensus statement of the European Atherosclerosis Society. Eur Heart J 34: 3478a-3490a, 2013.

OOSTERVEER DM, VERSMISSEN J, YAZDANPANAH M, HAMZA TH, SIJBRANDS EJ: Differences in characteristics and risk of cardiovascular disease in familial hypercholesterolemia patients with and without tendon xanthomas: a systematic review and meta-analysis. Atherosclerosis 207: 311-317, 2009.

PALACIOS L, GRANDOSO L, CUEVAS N, OLANO-MARTIN E, MARTINEZ A, TEJEDOR D, STEF M: Molecular characterization of familial hypercholesterolemia in Spain. Atherosclerosis 221: 137-142, 2012.

TAI DY, PAN JP, LEE-CHEN GJ: Identification and haplotype analysis of apolipoprotein B-100 Arg3500-->Trp mutation in hyperlipidemic Chinese. Clin Chem 44: 1659-1665, 1998.

TAYLOR A, PATEL K, TSEDEKE J, HUMPHRIES SE, NORBURY G: Mutation screening in patients for familial hypercholesterolaemia (ADH). Clin Genet 77: 97-99, 2010.

TICHY L, FREIBERGER T, ZAPLETALOVA P, SOSKA V, RAVCUKOVA B, FAJKUSOVA L: The molecular basis of familial hypercholesterolemia in the Czech Republic: spectrum of LDLR mutations and genotypephenotype correlations. Atherosclerosis 223: 401-408, 2012.

VAN AALST-COHEN ES, JANSEN AC, TANCK MW, DEFESCHE JC, TRIP MD, LANSBERG PJ, STALENHOEF AF, KASTELEIN JJ: Diagnosing familial hypercholesterolaemia: the relevance of genetic testing. Eur Heart $J$ 27: 2240-2246, 2006.

VOGT A: The genetics of familial hypercholesterolemia and emerging therapies. Appl Clin Genet 8: 27-36, 2015.

WIDHALM K, DIRISAMER A, LINDEMAYR A, KOSTNER G: Diagnosis of families with familial hypercholesterolaemia and/or Apo B-100 defect by means of DNA analysis of LDL-receptor gene mutations. J Inherit Metab Dis 30: 239-247, 2007. 